\title{
The Cancer and Non-Cancer Risk of Santiago Island (Cape Verde) Population due to Potential Toxic Elements Exposure from Soils
}

\author{
Marina M. S. Cabral Pinto ${ }^{1, *}$ (D), Maria M. V. Silva ${ }^{2}$ (D), Eduardo A. Ferreira da Silva ${ }^{3}$ and \\ A. Paula Marinho-Reis ${ }^{3}$ \\ 1 Geobiotec Research Centre and Center for Neuroscience and Cell Biology (CNC), \\ Department of Earth Sciences, University of Coimbra, 3030-790 Coimbra, Portugal \\ 2 Centre for Mechanical Engineering, Materials and Processes, Department of Earth Sciences, \\ University of Coimbra, 3030-790 Coimbra, Portugal; mmvsilva@ci.uc.pt \\ 3 Geobiotec Research Centre, Department of Geosciences, University of Aveiro, 3810-193 Aveiro, Portugal; \\ eafsilva@ua.pt (E.A.F.S.); pmarinho@ua.pt (A.P.M.R.) \\ * Correspondence: mcp@uc.pt
}

Received: 11 August 2017; Accepted: 1 September 2017; Published: 7 September 2017

\begin{abstract}
The hazard index (HI) and carcinogenic risk due to the exposure of some potentially toxic elements to the Santiago Island (Cape Verde) population were calculated, considering soil ingestion, inhalation, and dermal contact as exposure pathways. The topsoil of Santiago Island, compared with that of the upper continental crust, is enriched with $\mathrm{Co}, \mathrm{Cr}, \mathrm{Cu}, \mathrm{Ni}, \mathrm{V}, \mathrm{Zn}, \mathrm{Mn}$, and $\mathrm{Cd}$. Hazard indices (HIs) for these metals and the As exposures to the Santiago Island population were calculated, and these calculations were performed for children and adults. For children, HIs were higher than 1 for $\mathrm{Co}$, $\mathrm{Cr}$, and $\mathrm{Mn}$. Therefore, there is an indication of potential non-carcinogenic risk for children, due to the high $\mathrm{Co}(\mathrm{HI}=2.995), \mathrm{Cr}(\mathrm{HI}=1.329)$, and $\mathrm{Mn}(\mathrm{HI}=1.126)$ values in these soils. For the other elements, in adults, there is no potential non-carcinogenic risk. Cancer risk for $\mathrm{As}, \mathrm{Cd}, \mathrm{Cr}$, and $\mathrm{Ni}$ exposures, in adults and children, was calculated, and the results are mainly lower than the carcinogenic target risk of $1 \times 10^{-6}$ for As, Cd, and Ni. However, in adults, cancer risk is higher than the carcinogenic target risk for Cr. Regarding As, for children, the fraction due to Risk ingestion represents $51.6 \%$, while

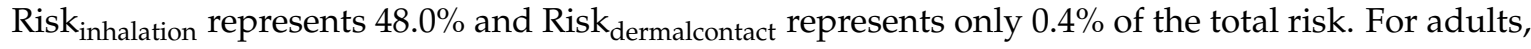
Risk $_{\text {inhalation }}$ represents $81.3 \%$, Risk ingestion $_{\text {represents }} 16.6 \%$, and Risk dermal contact $_{\text {represents }} 2.1 \%$. These results reflect the higher daily ingestion dose for children and the higher inhalation rate and higher dermal contact surface for adults. For the other elements, the cancer risk due to $\mathrm{Cr}, \mathrm{Ni}$, and $\mathrm{Cd}$ inhalation is always higher for adults than it is for children, reflecting the higher inhalation rate for adults.
\end{abstract}

Keywords: cancer risk; risk assessment; volcanic soils; Santiago Island

\section{Introduction}

Soils are natural resources, formed at the Earth's surface by the weathering of underlying rocks due to physical, chemical, and biologic factors. They support agriculture and the main carbon reservoir of the terrestrial carbon cycle, they act as a sink for pollutants, protecting groundwater from pollution, and they are also used as construction material and support. Therefore, they have very important social, environmental, and economic functions [1,2].

However, if contaminated or polluted, they can transfer potentially toxic elements (PTEs) to groundwater, to seepage waters and rivers [3-5], and to crops and vegetables that are used by humans and animals, and can consequently affect human health. The soil contamination may be natural due to 
rock composition [6]. Some elements can accumulate in topsoil to concentrations that are toxic to the plant, to the animal feeding on it, and to humans. Air quality may also be affected by contaminated soils due to the generation of airborne particles and dust [7]. In deeper soils, due to changes in $\mathrm{pH}$ and Eh, PTEs may be released into the groundwater, resulting in its contamination [8-13].

The chemical composition of dust, soils, and groundwater may cause metabolic changes that may favor the occurrence of endemic diseases in humans [14-20]. The role of F, I, Se, and As concentrations in the health of human populations is well documented in the scientific literature [21-26].

The high concentrations of PTE on topsoil can threaten human health (a) via soil ingestion by geophagism, rare in adults but quite common in children by hand-to-mouth intake; (b) by the inhalation of dust particles; (c) by dermal contact $[27,28]$, especially by farmers and construction workers; and (d) indirectly by ingestion of contaminated groundwater.

The geochemistry of the major, trace, and rare earth elements (REEs) of soils of Santiago Island (Cape Verde) has been studied to characterize the soils developed on volcanic rocks and Quaternary sediments, contributing to the establishment of a geochemical atlas of the island $[9,17,29,30]$.

The Mapping of Estimated Background Values (EBVs), the agricultural and residential Environmental Risk Index (ERI) for each element, and the agricultural and residential Multi-Element ERI (ME-ERI), which is the average of the ERIs of harmful elements in the soils of Santiago Island, were presented by Cabral Pinto et al. [30]. The present work follows the precedent study to better understand the relationships between environmental geochemistry and public health in a volcanic island that still preserves many pristine geochemical characteristics and where the anthropogenic action is not yet too strong. We present the hazard index (HI) and the carcinogenic risk due to the exposure of potentially toxic elements to the Santiago Island population, according to the Exposure Factors Handbook [31]. We consider soil ingestion, inhalation, and dermal contact as exposure pathways, because most of the population of the Island is rural, and the island is affected by strong winds (defined as "bruma seca"), which causes the mobilization of significant amounts of dust particles from soil [32].

\section{Geographic, Geologic, and Climate Settings and Soil Types}

Cape Verde is formed by 10 islands, located off the shore of Western African (Figure 1). The country capital is located on Santiago Island, which is the largest island. It is a mountainous island with a maximum altitude of $1394 \mathrm{~m}$. It has $215 \mathrm{~km}^{2}$ of arable area and estimated water resources of $56.6 \times 100 \mathrm{~m}^{3} /$ year at the surface and $42.4 \times 100 \mathrm{~m}^{3} /$ year underground [33].

The climate is semi-arid, with strong winds during the dry season, and a mean annual precipitation of $321 \mathrm{~mm}$, mainly due to torrential rains, in the wet season [34]. In the 1900-2012 years period, the mean historical monthly rainfall attained $347.7 \mathrm{~mm}$ and the highest value $(109.2 \mathrm{~mm})$ was recorded in September [35]. In the same period, the mean historical monthly temperature varied from $20.4^{\circ} \mathrm{C}$ in February to $25.5^{\circ} \mathrm{C}$ in September [35].

The islands are volcanic, intraplate, located over a submarine plateau known as the Cape Verde Rise, and relatively stable within the African Plate. The volcanism is a result of the interaction of a mantle plume with the fractured lithosphere $[36,37]$. Santiago Island is a shield volcano, with periods of intense volcanic activity, the emission of alkaline basaltic lava flows, and subaerial pyroclastic materials, separated by erosion and sedimentations periods [38]. A brief description of the lithostratigraphic formations of Santiago is presented in Figure 2a and Table 1. 


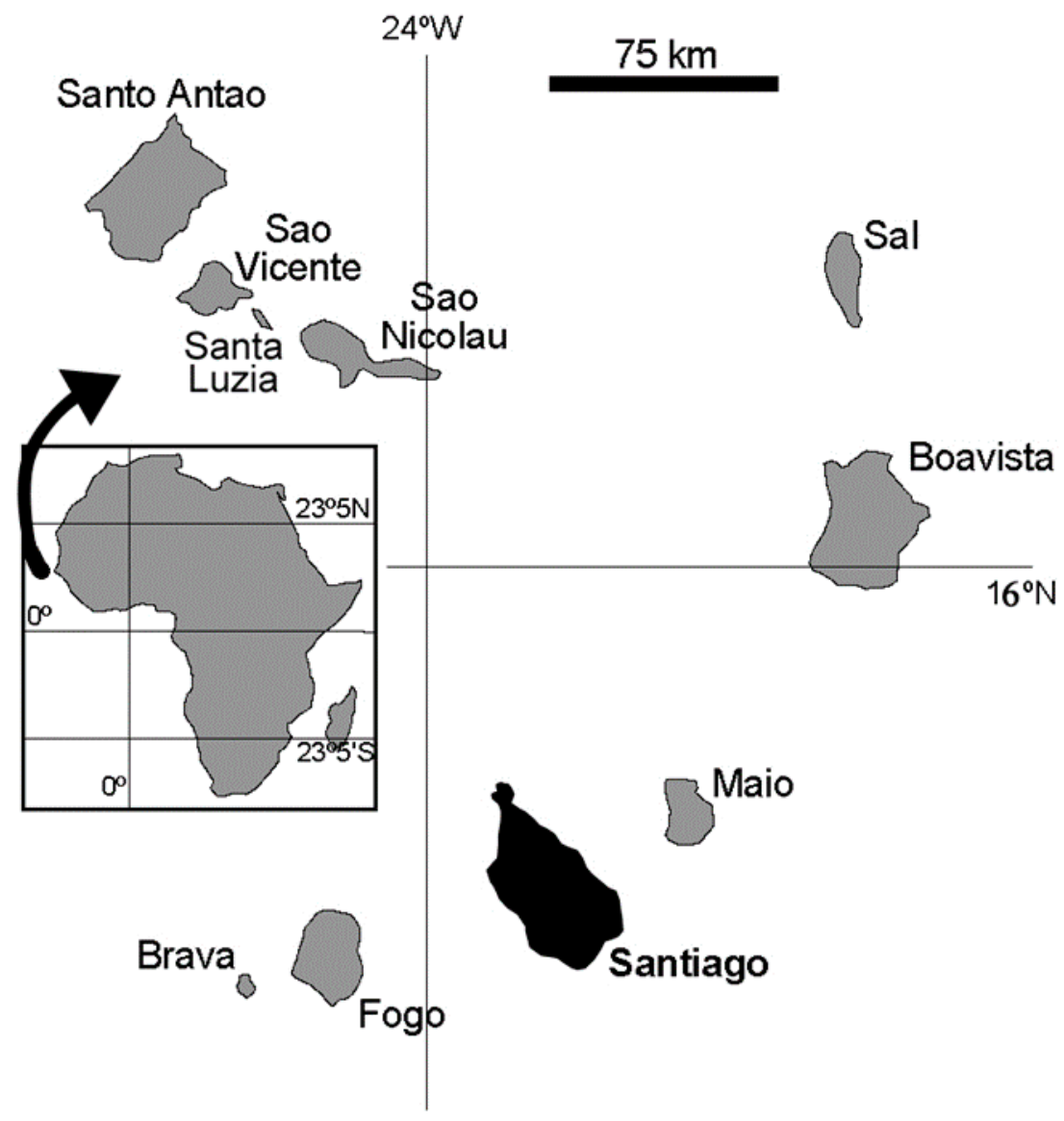

Figure 1. Cape Verde archipelago and its location.

(a)

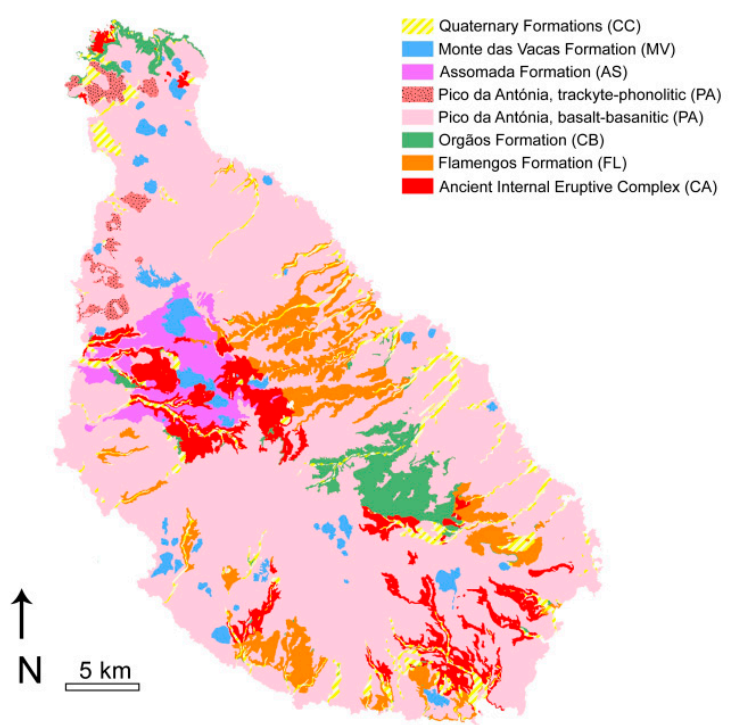

(b)

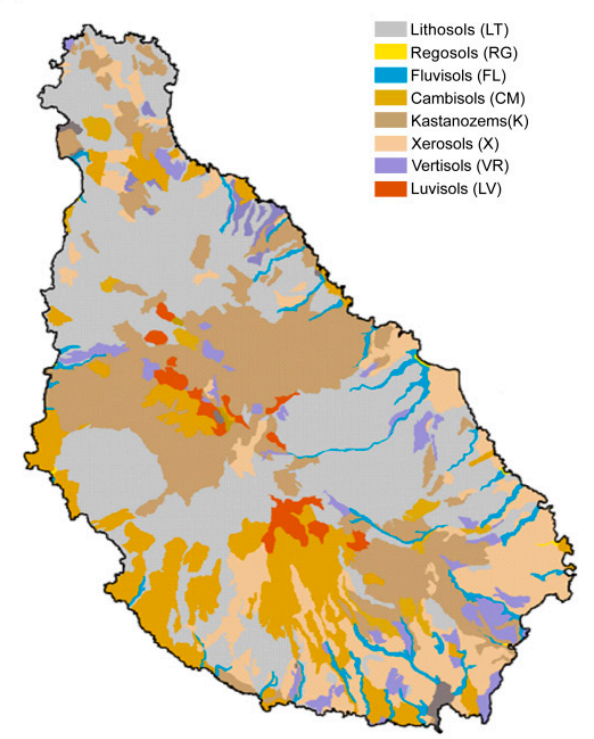

Figure 2. (a) Geological cartography of the island of Santiago, Cape Verde, adapted from [38]; (b) Adapted soil cartography of the island of Santiago according to FAO/UNESCO [39], adapted from [40]. 
Table 1. Brief description of each geological formation of the soils of Santiago Island.

\begin{tabular}{ccc}
\hline Geological Formation & Rock Type & Composition \\
\hline $\begin{array}{c}\text { CA-Ancient Internal } \\
\text { Eruptive Complex }\end{array}$ & $\begin{array}{c}\text { Subaerial and submarine lava flows and pyroclastic deposits; } \\
\text { dykes and intrusive rocks }\end{array}$ & $\begin{array}{c}\text { Basalts-basanites, } \\
\text { phonolites-trachytes } \\
\text { and carbonatites }\end{array}$ \\
\hline $\begin{array}{c}\text { FL_Flamengos } \\
\text { formation }\end{array}$ & Submarine lava flows with subordinated breccias and tuffs & Basanites \\
\hline CB—Orgãos Formation & Volcano-sedimentary deposits; rare lava flows & Diverse \\
\hline $\begin{array}{c}\text { PA—Pico da Antónia } \\
\text { Eruptive Complex }\end{array}$ & $\begin{array}{c}\text { Subaerial and submarine lava flows, dykes and pyroclastic } \\
\text { material; intercalated sedimentary deposits }\end{array}$ & $\begin{array}{c}\text { Basalts-basanites and } \\
\text { phonolites-trachytes }\end{array}$ \\
\hline $\begin{array}{c}\text { AS-Assomada } \\
\text { Formation }\end{array}$ & Subaerial lava flows and some pyroclastes & Basanites \\
\hline $\begin{array}{c}\text { MV-Monte das } \\
\text { Vacas Formation }\end{array}$ & Subaerial pyroclasts and small subordinated lava flows & Basanites \\
\hline $\begin{array}{c}\text { CC-Recent } \\
\text { sedimentary formations }\end{array}$ & Alluvial, aeolian, and marine deposits & Diverse \\
\hline
\end{tabular}

Figure $2 \mathrm{~b}$ presents the adapted soil cartography of Santiago Island, based on studies by $[9,41,42]$, according to the FAO/UNESCO classification. Table 2 shows a brief description of the soil cartography. The main soils are lithosols, regosols, xerosols, and cambisols. Kastanozems occur mainly in association with luvisols, which are the soil group typically used for agriculture in Cape Verde (Figure $2 \mathrm{~b}$ and Table 2).

Table 2. Brief description of each group of the soils of Santiago Island.

\begin{tabular}{|c|c|c|}
\hline $\begin{array}{l}\text { Pedological } \\
\text { Formation }\end{array}$ & Development Characteristics & Texture \\
\hline LT_Lithosols & $\begin{array}{l}\text { Immature incipient mineral soils with no or little } \\
\text { differentiation }(<20 \mathrm{~cm} \text { thickness). }\end{array}$ & $\begin{array}{l}\text { Low clay and organic matter contents and } \\
\text { high proportion of coarse-grained fractions. }\end{array}$ \\
\hline RG-Regosols & $\begin{array}{l}\text { Incipient mineral and undifferentiated soils. } \\
\text { No vegetation. }\end{array}$ & $\begin{array}{l}\text { Mainly sandy and gravel materials. Low } \\
\text { clay and organic matter contents. }\end{array}$ \\
\hline FV_Fluvisols & $\begin{array}{l}\text { Undifferentiated or show little differentiation. } \\
\text { Developed on alluvial deposits on the banks of } \\
\text { temporary or torrential streams. }\end{array}$ & Mainly sand and coarse particles. \\
\hline $\mathrm{CM}-$ Cambisols & $\begin{array}{l}\text { Immature (profile AC), non-climate } \\
\quad(20-30 \mathrm{~cm} \text { thickness). }\end{array}$ & $\begin{array}{l}\text { Mainly coarse-to-fine sand with high } \\
\text { proportion of slightly weathered } \\
\text { rock fragments. }\end{array}$ \\
\hline K-Kastanozems & $\begin{array}{c}\text { Developed soils, but with moderately or poorly } \\
\text { differentiated profiles and relatively rich in } \\
\text { organic matter. }\end{array}$ & $\begin{array}{l}\text { Fine-grained, mostly consisting of } \\
\text { clay materials. }\end{array}$ \\
\hline X-Xerosols & $\begin{array}{l}\text { Sub-arid soils, with surface decalcification } \\
\text { horizons and with some organic matter } \\
(0.8-1.8 \%)\end{array}$ & Mainly coarse-to-fine material. \\
\hline VR-Vertisols & Non-lytic soils. Developed soils (ABC profile). & Fine-grained, up to $30 \%$ clay content. \\
\hline LV_- Luvisols & Developed soils (ABC profile). & $\begin{array}{l}\text { High proportion of fine-grained particles } \\
\text { (mainly clay). }\end{array}$ \\
\hline
\end{tabular}

\section{Methodologies}

\subsection{Sampling, Chemical, and Statistical Analysis}

The sampling, analytical, and statistical methodologies were fully described in [30], so only a brief description will be provided in the present paper. A total of 249 topsoil composite samples, free of potential anthropogenic influence, was collected at a spatial resolution of 0.3 sites $/ \mathrm{km}^{2}$ (identified by GPS). Duplicate field samples were collected at every 10th site. The $<2 \mathrm{~mm}$ fraction was pulverized 
to $<75 \mu \mathrm{m}$, digested with aqua regia and analyzed by ICP-MS (Perkin Elmer, Vancouver, BC, Canada) at the ACME Analytical Laboratories.

Lab-duplicate samples were taken at every 30 samples to calculate the analytical precision (which was better than $10 \%$ ), and certified standard materials were analyzed to determine accuracy.

Variance analysis was performed to test the reliability of the data to be used in the statistical analysis. The estimated background values (EBV-S) of the analyzed elements were estimated as the median of the data limited by the Tukey Range. Principal component analysis (PCA) was performed with Matlab 10 software [30] to determine the associations of metals.

\subsection{Risk Assessment}

The environmental risk index (ERI) was calculated for PTEs by [30] using Canadian [43] and Dutch [44] legislations for soils. For each element, ERI $=C(s) / P$, where computed. $C(s)$ is the element concentration at sampling site $\mathrm{s}$, and $\mathrm{P}$ is the permissive level of that element, according to the legislations.

Non-cancer risk is represented in terms of hazard index (HI) for multiple substances and/or exposure pathways [31]. HI is the sum of the hazard quotient (HQ), for each element and each pathway, and if $\mathrm{HI}<1$, there is a very low chance of non-carcinogenic risk. HQ $=\mathrm{ADD} / \mathrm{RfD}$, where ADD is the average daily dose of an element to which a person is exposed, and RfD is the reference dose [31], below which the non-cancer risk is negligible, presented in Table S1.

HIs were calculated for $\mathrm{Co}, \mathrm{Cr}, \mathrm{Cu}, \mathrm{Ni}, \mathrm{V}, \mathrm{As}, \mathrm{Zn}, \mathrm{Mn}$, and $\mathrm{Cd}$ exposure of the Santiago Island population, according to the Exposure Factors Handbook [31]. The equations (Equations (1)-(3)) used to calculate the average daily dose (ADD) for each pathway are those presented in [31].

$$
\begin{gathered}
\text { ADDingestion }=\frac{\text { Csoil } \times \mathrm{IngR} \times \mathrm{EF} \times \mathrm{ED}}{\mathrm{BW} \times \mathrm{AT}} . \\
\mathrm{ADDdermal}=\frac{\mathrm{C} \text { soil } \times \mathrm{SA} \times \mathrm{SAF} \times \mathrm{DA} \times \mathrm{EF} \times \mathrm{ED}}{\mathrm{BW} \times \mathrm{AT}} .
\end{gathered}
$$

$$
\text { ADDinhalation }=\frac{\text { Csoil } \times \mathrm{InhR} \times \mathrm{EF} \times \mathrm{ED}}{\mathrm{BW} \times \mathrm{AT} \times \mathrm{PEF}} .
$$

Csoil is the concentration of the element in the soil $\left(\mathrm{mg} \cdot \mathrm{kg}^{-1}\right)$ and we used the 95th percentile of the soil distribution values, presented in [30]. IngR is the soil ingestion rate, and we used $200 \mathrm{mg} \cdot \mathrm{d}^{-1}$ for children and $100 \mathrm{mg} \cdot \mathrm{d}^{-1}$ for adults [31]. EF is the exposure frequency, and we used 365 days, considering the inhabitants of the island. ED is the exposure duration, and we assumed that an inhabitant will spend half of his/her live exposed, so we assumed 6 years for children and 35 years for adults. AT is ED expressed in days for non-carcinogenic. For body weight (BW), we used $15 \mathrm{~kg}$ for children and $70 \mathrm{~kg}$ for adults. We assumed a life expectancy of 70 years.

The exposed skin area (SA) was taken as $2372 \mathrm{~cm}^{2}$ and $60,132 \mathrm{~cm}^{2}$ for children and adults, respectively. The used skin adherence factor (SAF) was $0.2 \mathrm{mg} \cdot \mathrm{cm}^{-2}$ and $0.07 \mathrm{mg} \cdot \mathrm{cm}^{-2}$ for children and adults, respectively, and the dermal absorption factor (DA) was 0.003 for As and 0.001 for other elements [31-46]. InhR is the inhalation rate taken as $7.6 \mathrm{~m}^{3} \cdot \mathrm{d}^{-1}$ and $20 \mathrm{~m}^{3} \cdot \mathrm{d}^{-1}$ for children and adults, respectively, and the particle emission factor (PEF) is $1.36 \times 10^{9} \mathrm{~m}^{3} \cdot \mathrm{kg}^{-1}$.

The carcinogenic risks were calculated for $\mathrm{As}, \mathrm{Cd}, \mathrm{Cr}$, and $\mathrm{Ni}$ exposure of the Santiago Island population (Equation (4)), according to the Exposure Factors Handbook [31] and using the slope factors (SF) values according to [46], presented in Table S1.

$$
\text { CancerRisk }=\sum(\text { ADDpathway } \times \text { SFpathway }) .
$$




\section{Results and Discussion}

The topsoil of Santiago Island is enriched with $\mathrm{Cd}, \mathrm{Ni}, \mathrm{Co}, \mathrm{Cu}, \mathrm{V}, \mathrm{Mn}, \mathrm{Cr}$, and $\mathrm{Zn}$ to upper crust values (UCCs) of [47], considering both the Estimated Background Values (EBVs) or the 95th percentile value calculated from the soil distribution values (Table 3).

Table 3. Estimated background values, 95 percentiles of Santiago soils $\left(\mathrm{mg} \cdot \mathrm{kg}^{-1}\right)$ and ratios of these values to upper continental crust (UCC) and published guidelines values (Gdl).

\begin{tabular}{lcccccccc}
\hline & EBV $^{\mathbf{1}}$ & P95(s) $^{\mathbf{1}}$ & UCC $^{\mathbf{2}}$ & Guidelines & EBV/UCC & P95(s)/UCC & EBV/Gdl & P95(s)/Gdl \\
\hline $\mathrm{As}$ & 0.6 & 1.92 & 4.8 & $11^{\mathrm{a}}$ & 0.1 & 0.4 & 0.1 & 0.2 \\
$\mathrm{Cd}$ & 0.20 & 0.4 & 0.09 & $0.8^{\mathrm{b}}$ & 2.22 & 4.4 & 1.1 & 0.5 \\
$\mathrm{Co}$ & 46.4 & 67.11 & 17.3 & $9^{\mathrm{a}}$ & 2.7 & 3.9 & 5.2 & 7.5 \\
$\mathrm{Cr}$ & 118 & 298 & 92 & $67^{\mathrm{a}}$ & 1.3 & 3.2 & 1.8 & 4.4 \\
$\mathrm{Cu}$ & 50.8 & 81.8 & 28 & $36^{\mathrm{b}}$ & 1.8 & 2.9 & 1.4 & 2.3 \\
$\mathrm{Mn}$ & 1293 & 1954 & 774.5 & - & 1.7 & 2.6 & - & - \\
$\mathrm{Ni}$ & 136.1 & 267.9 & 47 & $36^{\mathrm{b}}$ & 2.9 & 5.7 & 3.8 & 7.4 \\
$\mathrm{~V}$ & 169 & 260 & 97 & $86^{\mathrm{a}}$ & 1.7 & 2.7 & 2.0 & 3.0 \\
$\mathrm{Zn}$ & 79 & 120.2 & 67 & $140^{\mathrm{b}}$ & 1.2 & 1.8 & 0.6 & 0.9 \\
\hline
\end{tabular}

EBV: estimated background values [21]; P95(s): 95th percentile in Santiago soils [21]; UCC: upper continental crust [39]; Gdl: guidelines: a: Canadian [43] and b: Dutch Guidelines [44]. On Santiago Island, the soil geochemistry is mainly controlled by lithology, although some elements may have an anthropogenic influence, such as As, $\mathrm{Hg}$, $\mathrm{Cd}, \mathrm{Zn}$, and $\mathrm{Pb}$ [30]. Using the permissible values for agricultural soils in the calculations, their results have shown that soil of the entire island has an environmental risk index (ERI) above 1 for $\mathrm{Co}, \mathrm{Ni}, \mathrm{Cr}, \mathrm{V}$, and $\mathrm{Cu}$ [30].

The HQs for ingestion, dermal contact, and inhalation routes and HIs were calculated for the metals (Table 4), which showed enrichment compared to the UCCs, and for As, which is a toxic and carcinogenic element.

Table 4. Hazard quotient (HQ) values for various pathways and elements, hazard indices (HIs), and cancer risk resulting from exposure to soil elements on Santiago Island.

\begin{tabular}{|c|c|c|c|c|c|c|c|c|}
\hline & \multicolumn{2}{|c|}{ HQ Ingestion } & \multicolumn{2}{|c|}{ HQ Dermal } & \multicolumn{2}{|c|}{ HQ Inhalation } & \multicolumn{2}{|c|}{ HI } \\
\hline & Children & Adult & Children & Adult & Children & Adult & Children & Adult \\
\hline Co & 2.98 & $3.20 \times 10^{-1}$ & $8.34 \times 10^{-3}$ & $1.28 \times 10^{-3}$ & $4.16 \times 10^{-3}$ & $2.35 \times 10^{-3}$ & 2.99 & $3.23 \times 10^{-1}$ \\
\hline $\mathrm{Cr}$ & 1.32 & $1.42 \times 10^{-1}$ & $3.70 \times 10^{-3}$ & $5.66 \times 10^{-4}$ & $1.11 \times 10^{-3}$ & $6.26 \times 10^{-4}$ & 1.33 & $1.43 \times 10^{-1}$ \\
\hline $\mathrm{V}$ & $6.88 \times 10^{-1}$ & $7.37 \times 10^{-2}$ & $1.93 \times 10^{-3}$ & $2.94 \times 10^{-4}$ & $9.69 \times 10^{-4}$ & $5.46 \times 10^{-4}$ & $6.91 \times 10^{-1}$ & $7.45 \times 10^{-2}$ \\
\hline $\mathrm{Ni}$ & $1.78 \times 10^{-1}$ & $1.91 \times 10^{-2}$ & $4.98 \times 10^{-4}$ & $7.64 \times 10^{-5}$ & $1.11 \times 10^{-3}$ & $6.25 \times 10^{-4}$ & $1.80 \times 10^{-1}$ & $1.98 \times 10^{-2}$ \\
\hline $\mathrm{Cu}$ & $2.72 \times 10^{-2}$ & $2.92 \times 10^{-3}$ & $3.04 \times 10^{-4}$ & $1.16 \times 10^{-5}$ & $7.59 \times 10^{-7}$ & - & $2.75 \times 10^{-2}$ & - \\
\hline As & $8.44 \times 10^{-2}$ & $9.14 \times 10^{-3}$ & $2.36 \times 10^{-4}$ & $1.09 \times 10^{-4}$ & $4.72 \times 10^{-5}$ & $2.69 \times 10^{-5}$ & $8.47 \times 10^{-2}$ & $9.28 \times 10^{-3}$ \\
\hline $\mathrm{Zn}$ & $5.33 \times 10^{-3}$ & $5.72 \times 10^{-4}$ & $7.47 \times 10^{-5}$ & $2.28 \times 10^{-6}$ & $1.49 \times 10^{-7}$ & - & $5.41 \times 10^{-3}$ & - \\
\hline $\mathrm{Cd}$ & $5.33 \times 10^{-3}$ & $5.71 \times 10^{-4}$ & $5.97 \times 10^{-4}$ & $9.12 \times 10^{-5}$ & $1.49 \times 10^{-5}$ & $8.40 \times 10^{-6}$ & $5.95 \times 10^{-3}$ & $6.71 \times 10^{-4}$ \\
\hline \multirow[t]{3}{*}{$\mathrm{Mn}$} & 1.08 & $1.19 \times 10^{-1}$ & $3.03 \times 10^{-3}$ & - & $1.45 \times 10^{-2}$ & $8.40 \times 10^{-3}$ & 1.10 & $1.27 \times 10^{-1}$ \\
\hline & \multicolumn{2}{|c|}{ Cancer Risk Ingestion } & \multicolumn{2}{|c|}{ Cancer Risk Dermal } & \multicolumn{2}{|c|}{ Cancer Risk Inhalation } & \multicolumn{2}{|c|}{ Cancer Risk } \\
\hline & Children & Adult & Children & Adult & Children & Adult & Children & Adult \\
\hline As & $3.3 \times 10^{-9}$ & $2.1 \times 10^{-9}$ & $2.3 \times 10^{-11}$ & $2.6 \times 10^{-10}$ & $3.1 \times 10^{-9}$ & $1.0 \times 10^{-8}$ & $6.4 \times 10^{-9}$ & $1.2 \times 10^{-8}$ \\
\hline $\mathrm{Cr}$ & - & - & - & - & $3.9 \times 10^{-7}$ & $1.3 \times 10^{-6}$ & $3.9 \times 10^{-7}$ & $1.3 \times 10^{-6}$ \\
\hline $\mathrm{Ni}$ & - & - & - & - & $7.2 \times 10^{-9}$ & $2.4 \times 10^{-8}$ & $7.2 \times 10^{-9}$ & $2.4 \times 10^{-8}$ \\
\hline $\mathrm{Cd}$ & - & - & - & - & $7.8 \times 10^{-11}$ & $2.6 \times 10^{-10}$ & $7.8 \times 10^{-11}$ & $2.6 \times 10^{-10}$ \\
\hline
\end{tabular}

The selected elements are potentially toxic elements, and some (As, $\mathrm{Cd}, \mathrm{Cr}$, and $\mathrm{Ni}$ ) are also carcinogenic [46]. The pathways chosen were ingestion, inhalation, and dermal contact, and the calculations were performed for children and adults. Major neurodegenerative disorders, including Alzheimer's and Parkinson's disease, are characterized by the elevation of tissue metals, such as Fe, $\mathrm{Cu}, \mathrm{Mn}$, and $\mathrm{Zn}$ [48]. Environmental exposure to Mn can induce parkinsonism; although the long-term medical significance of this finding is unclear, the data are troubling and point to the need for further investigation of manganese's health risk [49]. 
The non-carcinogenic HIs for all nine elements are given in Table 4. For adults, the HIs were always less than 1, whereas for children they were higher than $1 \mathrm{for} \mathrm{Co}, \mathrm{Cr}$, and $\mathrm{Mn}$. The HI values of

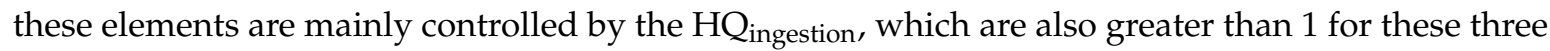
elements. For all elements, the $\mathrm{HQ}_{\text {ingestion }}$ is always the highest, while the $\mathrm{HQ}_{\text {inhalation }}$ is always the lowest (Figure 3).

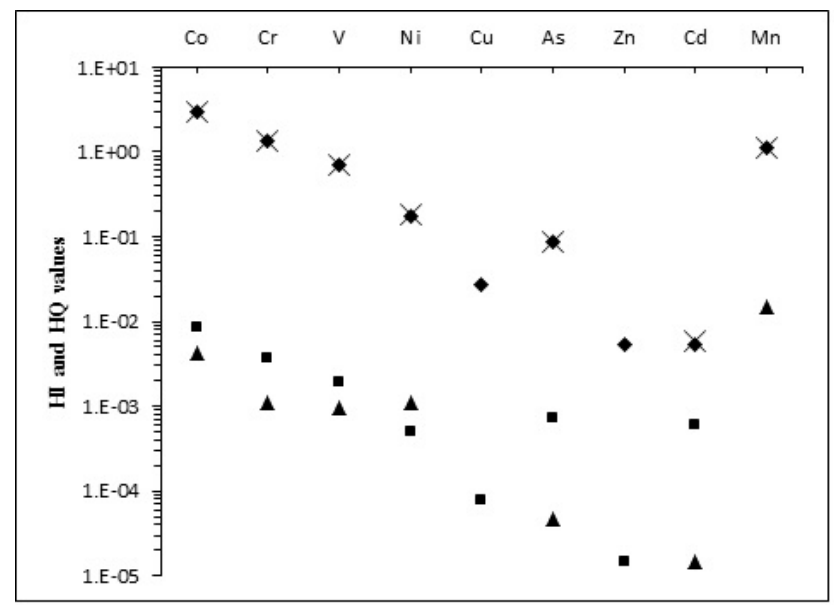

Figure 3. HIs and HQs for potentially toxic elements from Santiago Island. Symbols: His: crosses; HQs for ingestion: diamonds; HQs for dermal contact: squares; HQs for inhalation: triangles.

Therefore, there is an indication of potential non-carcinogenic risk for children, due to the high $\mathrm{Co}(\mathrm{HI}=2.995), \mathrm{Cr}(\mathrm{HI}=1.329)$, and $\mathrm{Mn}(\mathrm{HI}=1.126)$ values in soils. For the other elements, there is no potential non-carcinogenic risk for adults. For both children and adults, the $\mathrm{HI}$ is $\mathrm{Co}>\mathrm{Cr}>\mathrm{Mn}$. Compared to adults, the children's health index is greater, and the cumulative effect of these indices is also of greater concern for children.

The evaluation of cancer risk was performed only with those elements, which are potentially carcinogenic [46]. For As, ingestion, inhalation, and dermal contact exposure pathways were considered; however, for the other carcinogenic elements $(\mathrm{Cd}, \mathrm{Cr}$, and $\mathrm{Ni})$, only the inhalation risk was computed because the Risk Assessment Information System [46] does not present slope factors for the other exposures.

For children, the As cancer risk (Risk total ) is $6.38 \times 10^{-9}$ (Table 4) and of this, the fraction due to Risk ingestion $_{\text {represents }} 51.6 \%$, while Risk inhalation $_{\text {represents }} 48.0 \%$, and Risk dermalcontact $_{\text {represents }}$

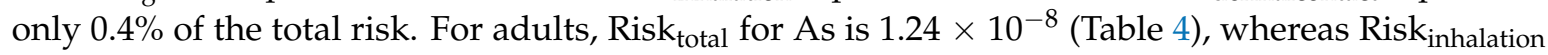

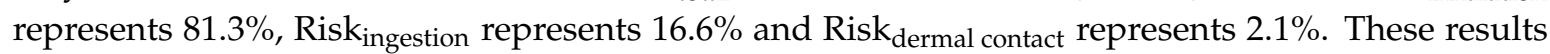
reflect the higher daily ingestion dose for children and the higher inhalation rate for adults. For adults, the cancer risk due to $\mathrm{Cr}, \mathrm{Ni}$, and $\mathrm{Cd}$ inhalation is always higher than it is for children, reflecting the higher inhalation rate of adults.

For adults, the results for cancer risk are higher than the carcinogenic target risk of $1 \times 10^{-6}$ [31] for $\mathrm{Cr}$ only, but these results underestimate the risk. The other pathways were not considered, and they can be particularly important for $\mathrm{Cr}$, which presents a cancer risk of $1.3 \times 10^{-6}$, very close to the target risk. The lack of RfD for some elements prevents a more complete evaluation of cancer risk (Table S1).

Santiago Island still has an almost pristine surface environment, and the topsoil composition is mainly determined by the composition of the underlying basic rock. These rocks are rich in siderophile elements, promoting a natural contamination of soils in $\mathrm{Co}, \mathrm{Cr}, \mathrm{Ni}, \mathrm{Cu}, \mathrm{V}, \mathrm{Zn}, \mathrm{Cd}$, and $\mathrm{Mn}$. Of these, $\mathrm{Co}, \mathrm{Cr}$, and $\mathrm{Mn}$ present a potential non-carcinogenic risk for children, a vulnerable subset of the population. On the other hand, the soil composition affects groundwater composition, so there is a flux of natural contamination from soils to the groundwater, which deserves to be evaluated. The inhabitants of Santiago Island depend on groundwater for consumption and for agriculture, and 
the flux water-vegetables-men also deserves evaluation because endemic diseases can be controlled with proper measures if its cause is well constrained.

\section{Conclusions}

The topsoil of Santiago Island, Cape Verde, has a geochemical composition, mainly controlled by the type of underlying rock, as most of the elements in the topsoil have primarily a geogenic origin.

The environmental risk index (ERI) calculations showed that Santiago Island topsoil is naturally contaminated with $\mathrm{Co}, \mathrm{Cr}, \mathrm{Cu}, \mathrm{Ni}$, and $\mathrm{V}$, because these elements have contents well above those allowed by Canadian and Dutch legislations for agricultural soils.

The non-carcinogenic His were calculated for nine potentially toxic elements, and they are always less than 1 for adults, considering that the soil contaminants enter the human body by soil ingestion, dermal contact, and inhalation of dust particles. For children, the non-carcinogenic HIs are 2.9952 for Co, 1.3293 for $\mathrm{Cr}$, and 1.1111 for Mn. For the other elements, they are less than 1 .

For adults, the cancer risk is greater than the carcinogenic target risk of $1 \times 10^{-6}$ for $\mathrm{Cr}$. However, these results may be underestimated, as only the inhalation risk was calculated for $\mathrm{Cr}, \mathrm{Ni}$, and $\mathrm{Cd}$. Moreover, soil contaminants may be indirectly ingested by groundwater and by crop and vegetable consumption, increasing the hazard and cancer risks.

There is need for an evaluation of the risks associated with groundwater consumption and diet on Santiago Island.

Supplementary Materials: The following are available online at www.mdpi.com/2076-3263/7/3/78/s1. Table S1: Reference doses and slope factors for different elements from different pathways.

Acknowledgments: The authors would like to thank the funding provided by the Portuguese Foundation for Science and Technology (SFRH/BPD/71030/2010 and UID/GEO/04035/2013 projects), Geobiotec Centre from Aveiro University, CNC, CEMUC and Geosciences Centre from Coimbra University. António Oliveira Cruz, Jorge Brito, and Luís Filipe Tavares are acknowledged for the logistic support provided in Santiago Island by the Jean Piaget University of Cape Verde. We also appreciate the support given by the National Institute of Agricultural Research and Development of Cape Verde. MCP acknowledges with great affection the field support provided by Ricardo Ramos during the fieldwork. The manuscript benefited from careful and constructive reviews by two anonymous reviewers.

Author Contributions: Marina Cabral Pinto performed the sampling, the pre-analytical treatment of samples, the statistical analysis and calculated the hazard index (HI) and carcinogenic risk Maria M. V. G. Silva participated in the field work. Eduardo Ferreira da Silva and Paula Marinho Reis participated in data analysis. Marina Cabral Pinto drafted the manuscript with collaboration of all authors and it was revised by all. All authors read and approved the final manuscript.

Conflicts of Interest: The authors declare no conflict of interest.

\section{References}

1. Vrščaj, B.; Poggio, L.; Marsan, F.A. A method for soil environmental quality evaluation for management and planning in urban areas. Landsc. Urban Plan. 2008, 88, 81-94. [CrossRef]

2. Cabral Pinto, M.M.S.; Marinho-Reis, A.P.; Almeida, A.; Ordens, C.M.; Silva, M.M.V.G.; Freitas, S.; Simões, M.R.; Moreira, P.I.; Dinis, P.A.; Diniz, M.L.; et al. Human predisposition to cognitive impairment and its relation with environmental exposure to potentially toxic elements. Environ. Geochem. Health 2017, 3, 1-18. [CrossRef] [PubMed]

3. Cabral Pinto, M.M.S.; Silva, M.M.V.G.; Neiva, A.M.R. Pollution of water and stream sediments associated with the Vale De Abrutiga Uranium Mine, Central Portugal. Mine Water Environ. 2004, 23, 66-75. [CrossRef]

4. Neiva, A.M.R.; Carvalho, P.C.S.; Antunes, I.M.H.R.; Cabral Pinto, M.M.S.; Santos, A.C.T.; Cunha, P.P.; Costa, M.M. Spatial variability of soils and stream sediments and the remediation effects in a Portuguese uranium mine area. Chem. Erde-Geochem. 2016, 76, 501-518. [CrossRef]

5. Wolkersdorfer, C.; Bowell, R. Contemporary Reviews of Mine Water Studies in Europe, Part 3. Mine Water Environ. 2005, 24, 58-76. [CrossRef] 
6. Cabral Pinto, M.M.S.; Dinis, P.A.; Silva, M.M.; Ferreira da Silva, E.A. Sediment generation on a volcanic island with arid tropical climate: A perspective based on geochemical maps of topsoils and stream sediments from Santiago Island, Cape Verde. Appl. Geochem. 2016, 75, 114-124. [CrossRef]

7. Gray, C.; McLaren, R.; Roberts, A. Atmospheric accessions of heavy metals to some New Zealand pastoral soils. Sci. Total Environ. 2003, 305, 105-115. [CrossRef]

8. Camobreco, V.J.; Richards, B.K.; Steenhuis, T.S.; Peverly, J.H.; McBride, M.B. Movement of heavy metals through undisturbed and homogenized soil columns. Soil Sci. 1996, 161, 740-750. [CrossRef]

9. Cabral Pinto, M.M.S.; Silva, M.M.V.G.; da Silva, E.A.F.; Dinis, P.A.; Rocha, F. Transfer processes of potentially toxic elements (PTE) from rocks to soils and the origin of PTE in soils: A case study on the island of Santiago (Cape Verde). J. Geochem. Explor. 2017, 6. [CrossRef]

10. Mirlean, N.; Roisenberg, A.; Chies, J.O. Metal contamination of vineyard soils in wet subtropics (southern Brazil). Environ. Pollut. 2007, 149, 10-17. [CrossRef] [PubMed]

11. Silva, M.M.V.G.; Cabral Pinto, M.M.S.; Carvalho, P.C.S. Major, trace and REE geochemistry of recent sediments from lower Catumbela River (Angola). J. Afr. Earth Sci. 2014, 115, 203-217. [CrossRef]

12. Cabral Pinto, M.M.S.; Silva, M.M.; Neiva, A.M.R.; Guimarães, F.; Silva, P.B. Uranium minerals from a portuguese variscan peraluminous granite, its alteration, and related uranium-quartz veins. In Uranium: Compounds, Isotopes and Applications; Wolfe, G.H., Ed.; Nova Science: New York, NY, USA, 2009; pp. $287-318$.

13. Reis, A.P.M.; Shepherd, T.; Nowell, G.; Cachada, A.; Duarte, A.C.; Cave, M.; Wragg, J.; Patinha, C.; Dias, A.; Rocha, F.; et al. Source and pathway analysis of lead and polycyclic aromatic hydrocarbons in Lisbon urban soils. Sci. Total Environ. 2016, 573, 324-336. [CrossRef] [PubMed]

14. Shamberger, R.J. Trace Elements in Health: A Review of Current Issues; Rose, J., Ed.; Cambridge University Press: Cambridge, UK, 1983; pp. 167-181.

15. Centeno, J.A.; Mullick, F.G.; Martinez, L.; Page, N.P.; Gibb, H.; Longfellow, D.; Thompson, D.; Ladich, E.R. Pathology Related to Chronic Arsenic Exposure. Environ. Health Perspect. 2002, 110, 883-886. [CrossRef] [PubMed]

16. Candeias, C.; Silva, E.F.; Ávila, P.F.; Teixeira, J.P. Identifying sources and assessing potential risk of exposure to heavy metals and hazardous materials in mining areas: The case study of Panasqueira mine (Central Portugal) as an example. Geosciences 2014, 4, 240-268. [CrossRef]

17. Cabral Pinto, M.M.S.; Silva, E.A.; Silva, M.M.; Melo-Gonçalves, P.; Candeias, C. Environmental Risk Assessment Based on High-Resolution Spatial Maps of Potentially Toxic Elements Sampled on Stream Sediments of Santiago, Cape Verde. Geosciences 2014, 4, 297-315. [CrossRef]

18. Patinha, C.; Reis, A.P.; Dias, A.C.; Abduljelil, A.A.; Noack, Y.; Robert, S.; Cave, M.; da Silva, E.F. The mobility and human oral bioaccessibility of $\mathrm{Zn}$ and $\mathrm{Pb}$ in urban dusts of Estarreja (N Portugal). Environ. Geochem. Health 2015, 37, 115-131. [CrossRef] [PubMed]

19. Reis, A.P.; Costa, S.; Santos, I.; Patinha, C.; Noack, Y.; Wragg, J.; Sousa, A.J. Investigating relationships between biomarkers of exposure and environmental copper and manganese levels in house dusts from a Portuguese industrial city. Environ. Geochem. Health 2015, 37, 725-744. [CrossRef] [PubMed]

20. Wu, S.; Peng, S.; Zhang, X.; Wu, D.; Luo, W.; Zhang, T.; Zhou, S.; Yang, G.; Wan, H.; Wu, L. Levels and health risk assessments of heavy metals in urban soils in Dongguan, China. J. Geochem. Explor. 2015, 148, 71-78. [CrossRef]

21. Rayman, M.P. The importance of selenium to human health. Lancet 2000, 356, 233-241. [CrossRef]

22. Tchounwou, P.B.; Patlolla, A.K.; Centeno, J.A. Carcinogenic and systemic health effects associated with arsenic exposure-A critical review. Toxicol. Pathol. 2003, 31, 575-588. [CrossRef] [PubMed]

23. Charlet, L.; Polya, D.A. Arsenic in shallow, reducing groundwater in southern Asia: An environmental health disaster. Elements. 2006, 2, 91-96. [CrossRef]

24. Dissanayake, C.B.; Chandrajith, R. Introduction to Medical Geology Focus on Tropical Environments; Springer: New York, NY, USA, 2009.

25. Tisserand, D.; Pili, E.; Hellmann, R.; Boullier, A.M.; Charlet, L. Geogenic arsenic in groundwater in the western Alps. J. Hydrol. 2014, 518, 317-325. [CrossRef]

26. Centeno, J.A.; Finkelman, R.B.; Selinus, O. Medical geology: Impacts of the natural environment on public health. Geosciences 2016, 6, 8. [CrossRef]

27. Sun, Y.; Zhou, Q.; Xie, X.; Liu, R. Spatial, sources and risk assessment of heavy metal contamination of urban soils in typical regions of Shenyang, China. J. Hazard. Mater. 2010, 174, 455-462. [CrossRef] [PubMed] 
28. Xie, Y.; Chen, T.B.; Lei, M.; Yang, J.; Guo, Q.J.; Song, B. Spatial distribution of soil heavy metal pollution estimated by different interpolation methods: Accuracy and uncertainty analysis. Chemosphere 2011, 82, 468-476. [CrossRef] [PubMed]

29. Marques, R.; Prudêncio, M.I.; Rocha, F.; Cabral Pinto, M.M.S.; Silva, M.M.V.; Ferreira da Silva, E.A. REE and other trace and major elements in the topsoil layer of Santiago Island, Cape Verde. J. Afr. Earth Sci. 2012, 64, 20-33. [CrossRef]

30. Cabral Pinto, M.M.S.; Ferreira da, S.E.A.; Silva, M.M.V.G.; Melo-Gonçalves, P. Heavy metals of Santiago Island (Cape Verde) top soils: Estimated Background Value maps and environmental risk assessment. J. Afr. Earth Sci. 2015, 101, 162-176. [CrossRef]

31. United States Environmental Protection Agency (USEPA). Exposure Factors Handbook 2011. Available online: https: / / cfpub.epa.gov/ncea/risk/recordisplay.cfm?deid=236252 (accessed on 4 September 2017).

32. Almeida-Silva, M.; Almeida, S.M.; Freitas, M.C.; Pio, C.A.; Nunes, T.; Cardoso, J. Impact of Sahara dust transport on Cape Verde atmospheric element particles. J. Toxicol. Environ. Health 2013, 76, 240-251. [CrossRef] [PubMed]

33. United Nations Development Programme. United Nations Development Program for Cape Verde; United Nations Development Programme: New York, NY, USA, 1993.

34. Instituto Nacional de Meteorologia e Geofisica (INMG). Climatologic Data of Some Stations in Santiago Island, Praia, Cabo Verde; Internal Report; Instituto Nacional de Meteorologia e Geofisica (INMG): Rome, Itlay, 2005.

35. CCKP: Climate Change Knowledge Portal. 2015. Available online: http://sdwebx.worldbank.org/ climateportal/index.cfm?page=country_historical_climateThisRegion=Africa\&ThisCCode=CPV (accessed on 4 September 2017).

36. Williams, C.; Hill, I.; Young, R.; White, R.S. Fracture Zones Across the Cape Verde Rise, NE Atlantic. J. Geol. Soc. 1990, 147, 851-857. [CrossRef]

37. Millet, M.A.; Doucelance, R.; Schiano, P.; David, C.; Bosp, C. Mantle plume heterogeneity versus shallow-level interactions: A case study, the São Nicolau Island, Cape Verde archipelago. J. Volcanol. Geotherm. Res. 2008, 176, 265-276. [CrossRef]

38. A Geologia da ilha de Santiago (Cabo Verde). Available online: http://memoria-africa.ua.pt/Catalog/ ShowRecord.aspx?MFN=41781 (accessed on 4 September 2017).

39. Hartemink, A.E.; Krasilnikov, P.; Bockheim, J.G. Soil maps of the world. Geoderma 2013, 207-208, $256-257$. [CrossRef]

40. Hernandez, R.V.A. Caracterização dos Solos da ilha de Santiago (Cabo Verde) Numa Perspectiva de Sustentabilidade Ambiental. Master's Thesis, Aveiro University, Aveiro, Portugal, 2008.

41. Faria, X. Os Solos da ilha de Santiago; Est Ens Doc; Junta de Investigações do Ultramar: Lisboa, Portugal, 1970. (In Portuguese)

42. Carta de zonagem agro-ecológica e de vegetação de Cabo Verde. Available online: http://www.fmsoares. pt/aeb/biblioteca/livro.php?registo=007287 (accessed on 4 September 2017).

43. Ministry of the Environment. Soil, Groundwater and Sediment Standards for Use under Part XV.1 of the Environmental Protection Act. Ministry of the Environment. Available online: https://www.ontario. $\mathrm{ca} /$ page/soil-ground-water-and-sediment-standards-use-under-part-xv1environmental-protection-act (accessed on 4 September 2017).

44. Ministry of Housing, Spatial Planning and the Environment (VROM). Circular on Target Values and Intervention Values for Soil Remediation. The Netherlands Government Gazette, No. 39, Ministry of Housing, Spatial Planning and Environment, Directorate General for Environmental Protection, Department of Soil Protection. Available online: http:/ / www.esdat.net/Environmental\%20Standards/Dutch/annexS_ I2000Dutch\%20Environmental\%20Standards.pdf https: / cfpub.epa.gov/ncea/risk/recordisplay.cfm?deid= 236252; (accessed on 3 September 2017).

45. USEPA. United States Environmental Protection Agency. Risk Assessment Guidance for Superfund: Volume III-Part A, Process for Conducting Probabilistic Risk Assessment; EPA 540-R-02-002. 2001. Available online: https:/ / www.epa.gov/sites/production/files/2015-09/documents/rags3adt_complete.pdf (accessed on 4 September 2017).

46. USDE. U.S. Department of Energy. The Risk Assessment Information System (RAIS). U.S. Department of Energy's Oak Ridge Operations Office: Oak Ridge, TN, USA, 2013. Available online: https:/ / rais.ornl.gov/ (accessed on 4 September 2017). 
47. Rudnick, R.L.; Gao, S. Composition of the Continental Crust. Treatise Geochem. 2003, 3, 659. [CrossRef]

48. Barnham, K.J.; Bush, A.I. Metals in Alzheimer's and Parkinson's diseases. Curr. Opin. Chem. Biol. 2008, 12, 222-228. [CrossRef] [PubMed]

49. Ahlskog, J.E. The New Parkinson's Disease, 2nd ed.; Oxford University Press: New York, NY, USA, 2016 ; p. 544. 